\title{
KECEMASAN ANAK DITINJAU DARI KECEMASAN ORANG TUA DI RSU. BHAKTI HUSADA KRIKILAN
}

\author{
Review Child's Anxiety from Parents' Anxiety in Bhakti Husada Krikilan General Hospital
}

\author{
Eko Prabowo ${ }^{1}$, Lediana Oktaviani ${ }^{2}$
}

\section{Prodi S1 Keperawatan Fakultas Ilmu Kesehatan Universitas Bakti Indonesia Banyuwangi \\ 2. Program Studi Pendidikan Ners IIK Surya Mitra Husada Kediri}

\section{Riwayat artikel}

Diajukan: 12 Agustus 2021

Diterima: 22 Agustus 2021

\section{Penulis Korespondensi: \\ - Eko Prabowo \\ - Prodi S1 Keperawatan Fakultas Ilmu Kesehatan Universitas Bakti Indonesia Banyuwangi e-mail: prabowo95@gmail.com}

\section{Kata Kunci:}

Kecemasan, Hospitalisasi

\begin{abstract}
Abstrak
Pendahuluan : Kegelisahan yang terjalin pada anak hospitalisasi bisa picu oleh perceraian yang ditunjukkan dengan mogok makan, meratap serta tidak kooperatif kepada tenaga kesehatan. Minimnya pengawasan menjadikan anak mudah marah serta kasar, hilangnya kontrol pada diri serta body image Tujuan Tujuan penelitian ini adalah untuk mengetahui Kecemasan anak ditinjau dari kecemasan orang tua di RSU. Bhakti Husada Krikilan. Metode Dalam penelitian ini menggunakan desain correlational dengan jenis penelitian yang digunakan adalah deskriptif analitik. Populasi dalam penelitian ini adalah rata-rata pasien anak beserta orang tuanya selama 3 bulan terakhir di Ruang Rawat Inap di RSU. Bhakti Husada Krikilan sebanyak 60 orang. Tehnik sampling mempergunakan Simple random. Alat untuk proses pengumpulan data adalah lembar kuesioner, selanjutnya dianalisa dengan uji statistik Rank Spearman. Keputusan diambil dengan membandingkan nilai $\mathrm{p}$ value $<0.05$. Hasil: Berdasarkan hasil penelitian menunjukkan bahwa dari 49 responden menunjukkan bahwa sebagian besar responden memiliki kecemasan orang tua dalam kategori sedang sebanyak 33 orang $(67.3 \%)$. Sedangkan sebagian besar responden memiliki kecemasan anak dalam kategori berat sebanyak 28 orang $(57.1 \%)$. Berdasarkan hasil uji Rank Spearman, diketahui bahwa ada hubungan Kecemasan anak ditinjau dari kecemasan orang tua di RSU. Bhakti Husada Krikilan Banyuwangi Tahun 2020 karena nilai $p$ value $<0.05$ yaitu 0.25 ). Kesimpulan: Orang tua dengan perasaan cemas berlebih cenderung lebih takut terhadap hal-hal yang belum pasti. Ini membuat mereka tidak memperhatikan betul apa yang sebenarnya sedang terjadi dan apa yang ada di hadapan mereka. Sehingga, hal tersebut akan membuat pola asuh tidak berjalan sebagaimana mestinya. Kondisi inilah yang ikut memicu terjadinya kecemasan pada anak. Untuk itu perlu kiranya meningkatkan pendampingan kepada anak untuk memberikan rasa aman dan nyaman sehingga kecemasan anak akan menurun.
\end{abstract}

\section{Abstract}

Background: Anxiety that occurs in hospitalized children can be caused by separation which is indicated by refusing to eat, crying and being uncooperative with health workers. Loss of control causes children to become irritable and aggressive, loss of self-concept and body image. Objective: The purpose of this study was to determine the anxiety of children in terms of the anxiety of parents in the RSU. Bhakti Husada Krikilan .Method: This study uses a correlational design with the type of research used is descriptive analytic. The population in this study was the average of pediatric patients and their parents during the last 3 months in the Inpatient Room at the RSU. Bhakti Husada Krikilan as many as 60 people. Sampling technique using simple random. The tool for the data collection process is a questionnaire sheet, which is then analyzed by the Spearman Rank statistic test. The decision was taken by comparing the $\mathrm{p}$ value $<0.05$. Results : Based on the results of the study showed that from 49 respondents showed that most of the respondents had parental anxiety in the moderate category as many as 33 people $(67.3 \%)$. While most of the respondents had child anxiety in the severe category as many as 28 people $(57.1 \%)$. Based on the results of the Spearman Rank test, it is known that there is a relationship between children's anxiety in terms of parental anxiety at the RSU. Bhakti Husada Krikilan Banyuwangi in 2020 because the p value $<0.05$, which is 0.25). Conclusion: Parents with excessive anxiety tend to be more afraid of things that are uncertain. This keeps them from paying close attention to what is really going on and what is in front of them. So, this will make parenting not work as it should. This condition also triggers anxiety in children. For this reason, it is necessary to increase assistance to children to provide a sense of security and comfort so that children's anxiety will decrease. 


\section{PENDAHULUAN}

Di rumah sakit, anak kerap menemukan lingkungan yang asing. Kerapkali mereka menghadapi metode yang menimbulkan rasa perih, kehilangan kemandirian dan berbagai hal lain. kegelisahan yang terjalin pada anak hospitalisasi bisa picu oleh perceraian yang ditunjukkan dengan mogok makan, meratap serta tidak kooperatif kepada tenaga kesehatan. Minimnya pengawasan menjadikan anak mudah marah serta kasar, hilangnya kontrol pada diri serta body image menyebabkan anak berespon terhadap nyeri dengan menggerenyotkan bibir wajah, meratap, menggigit bibir, menendang bahkan memukul dan berlari pergi (Wong dalam Rejeki, 2012).

Bersumber pada data World Health Organization dalam Burnsnader etall,( 2014), 3- 10\% anak dirawat di Amerika Serikat baik anak usia toddler, prasekolah ataupun anak umur sekolah. Di Indonesia sendiri jumlah anak yang dirawat pada tahun 2014 sebesar $15,26 \%$. Riset yang dilakukan oleh Lemos et angkatan laut(AL)( 2016) membuktikan persentase anak umur prasekolah( 3- 6 tahun) yang dirawat dirumah sakit sebesar 52, 38\% sebaliknya persentase anak umur sekolah( 7 11 tahun) ialah 47, 62\%. Perihal ini membuktikan kalau anak umur prasekolah lebih rentan terserang penyakit dan takut saat memperoleh penanganan dirumah sakit( Salmela, dalam Ramdaniati, 2016). Bersumber pada riset pendahuluan yang dilakukan periset pada tanggal 2 hingga $3 \mathrm{Mei}$ 2019 di Ruang Jaga Bermalam Anak RSU. Bhakti Husada Krikilan terjalin kenaikan jumlah penderita anak sebesar 11, 4\%, dimana pada tahun 2017 jumlah anak yang dirawat inap sebesar 1. 267 penderita, serta tahun 2018 jumlah anak yang dirawat inap sebesar 1. 594 penderita serta 5,77\% dari penderita anak yang dirawat dipulangkan tanpa persetujuan dokter sebab anak menolak perawatan dan tidak kooperatif.

Kegelisahan yang dirasakan anak hospitalisasi itu wajib ditangani sesegera mungkin, sebab keterlambatan dalam penindakan kegelisahan ini, akan berdampak buruk pada proses pemulihan anak.(Supartini, 2012) menyatakan pengaruh hospitalisasi serta kegelisahan yang dirasakan oleh anak bisa mengganggu tumbuh kembang anak juga berpengaruh pada cara pengobatan. Orang tua menghadapi tantangan pada diri sendiri seperti stress akibat situasi anak sepanjang pengobatan di rumah sakit. Pengalaman stress terjadi pada orang tua disebabkan oleh minimnya informasi yang didapatkan tentang kondisi anak, diagnosis, konsep penyembuhan serta pengecekan diagnostik. Stress pada orang tua biasanya berupa perwujudan over protektif pada anak. Alhasil anak merasakan adanya ancaman bahaya pada dirinya. Situasi inilah yang dapat menimbulkan kegelisahan pada anak (Majdaleni, 2014).

Peran serta orang tua dalam mengurangi eefek negatif akibat hospitalisasi bagi Wong, Hockenberry\&amp; Marylin,( 2017) ialah dengan ikut dalam peerawatan anak yakni orang tua ikut tinggal di rumah sakit, menjaga kontak tetap dekat dengan sang anak, mempersiapkan psikologis anak guna menghadapi tindakan prosedur yang hendak dilaksanan serta senantiasa memberian pengertian dan motivasi psikologis anak. Bila anak hendak dirawat di rumah sakit dalam kurun waktu yang lama, orang tua dapat membawa serta mainan yang disukai anak, membacakan buku- buku dongeng, bermain dengan anak di rumah sakit dan bermain dengan tenaga kesehatan yang bisa mengasyikkan.

Dari fenomena- fenomena diatas membuat pengarang terpikat buat mempelajari kasus itu dengan judul "Kecemasan anak ditinjau dari kecemasan orang tua di RSU. Bhakti Husada Krikilan".

\section{METODE}

Jenis penelitian ini menggunakan jenis penelitian correlational dengan pendekatan Cross Sectional. Penelitian ini dilaksanakan di Ruang Rawat Inap RSU. Bhakti Husada Krikilan dengan waktu antara 01 Pebruari31 Maret 2020. Populasi dalam penelitian 
ini adalah rata-rata pasien anak beserta orang tuanya selama 3 bulan terakhir di Ruang Rawat

Inap di RSU. Bhakti Husada Krikilan sebanyak 60 orang. Jumlah sampel yakni 49 orang dengan teknik sampling consecutive sampling. Instrument pada variable kecemasan orang tua adalah kuesioner yang sudah dilakukan modifikasi dahulu dari hasil penelitian sebelumnya, yaitu penelitian yang dilakukan oleh Fauzy dalam Nurmi (2016). Dari hasil perhitungan diperoleh angka $r$ hitung 0.400-0.500 lebih dari $r$ table 0.360 pada CI $95 \%$, sehingga disimpulkan valid pada 28 item instrument kecemasan. Sementara itu alpha Cronbach mendekati satu (part $1=0.775$ dan part $2=0.785$ ) dengan koefisien spearman brown 0.973 , sehingga bisa disimpulkan instrument kecemasan dikatakan reliabel (Nurmi, 2016)

Instrumen pada variable kecemasan anak adalah hasil modifikasi pengukuran Spench Children Anxiety Scale (Parent Report) yang dimodifikasi oleh Saputro (2017). Dari hasil perhitungan diperoleh angka $r$ hitung 0.947 lebih dari $r$ table 0.514 pada CI $95 \%$, sehingga disimpulkan valid pada 25 item instrument kecemasan. Sementara itu alpha Cronbach mendekatisatu (part $1=0.953$ dan part $2=0.949$ ) dengan koefisien spearman brown 0.973 , sehingga bisa disimpulkan instrument kecemasan dikatakan reliabel (Saputro, 2017).

Analisi statistic yang digunakan pada penelitian ini adalah adalah Korelasi Spearman (Spearman Rank Order Correlation) dengan $\mathrm{p}$ value $<0,05$.

\section{HASIL DAN PEMBAHASAN}

\section{HASIL}

1. Data Umum

Tabel Distribusi Umur anak di RSU. 1 Bhakti Husada Krikilan Banyuwangi 01 Juli-31 Agustus 2020

\begin{tabular}{|c|c|c|}
\hline Usia anak & f & $\%$ \\
\hline Usia 0-3 th & 24 & 49 \\
\hline Usia 4-5 th & 25 & 51 \\
\hline Jumlah & 49 & 100 \\
\hline
\end{tabular}

Berdasarkan table 1 diatas diketahui sebagian besar responden berjenis kelamin perempuan sebanyak 27 orang $(55 \%)$

Tabel Distribusi Jenis Kelamin anak di 2 RSU. Bhakti Husada Krikilan Banyuwangi 01 Juli-31 Agustus 2020

\begin{tabular}{|c|c|c|}
\hline $\begin{array}{c}\text { Jenis } \\
\text { Kelamin }\end{array}$ & $\mathrm{f}$ & $\%$ \\
\hline Laki-laki & 22 & 45 \\
\hline Perempuan & 27 & 55 \\
\hline Jumlah & 49 & 100 \\
\hline
\end{tabular}

Berdasarkan table 2 diatas diketahui sebagian besar responden berjenis kelamin perempuan sebanyak 27 orang (55\%).

Tabel Distribusi usia orang tua di 3 RSU. Bhakti Husada Krikilan Banyuwangi $01 \quad$ Juli-31 Agustus2020

\begin{tabular}{|c|c|c|}
\hline $\begin{array}{c}\text { Usia } \\
\text { orang tua }\end{array}$ & $\mathrm{f}$ & $\%$ \\
\hline $20-30$ th & 17 & 35 \\
\hline $41-40$ th & 18 & 37 \\
\hline$>40$ th & 14 & 28 \\
\hline Jumlah & 49 & 100 \\
\hline
\end{tabular}

Berdasarkan table 3 diatas diketahui hamper setengah responden ber usia 31-40 tahun sebanyak 18 orang (37\%)

Tabel 4. Distribusi usia orang tua di RSU. Bhakti Husada Krikilan Banyuwangi 01 Juli-31 Agustus 2020

\begin{tabular}{|c|c|c|}
\hline $\begin{array}{c}\text { Usia orang } \\
\text { tua }\end{array}$ & $\mathrm{f}$ & $\%$ \\
\hline $20-30$ th & 17 & 35 \\
\hline $41-40$ th & 18 & 37 \\
\hline$>40$ th & 14 & 28 \\
\hline Jumlah & 49 & 100 \\
\hline
\end{tabular}

Berdasarkan table 4 diatas diketahui hamper setengah responden ber usia 31-40 tahun sebanyak 18 orang (37\%)

Tabel 5. Hasil uji statistik Korelasi Rank Spearman hubungan Kecemasan anak ditinjau dari kecemasan orang tua di RSU. Bhakti Husada Krikilan Banyuwangi 01 Juli-31 Agustus 2020 


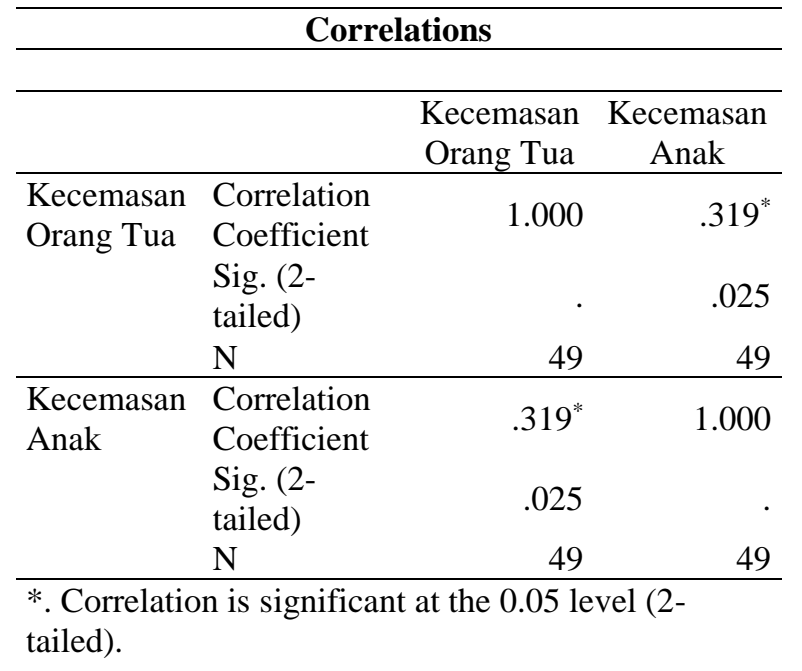

Berdasarkan table 5 diatas diketahui bahwa hasil uji statistic dengan menggunakan uji korelasi Rank Spearman didapatkan $\alpha$ 0.025. Untuk menguji hipotesa peneliti menggunakan nilai $\alpha$. Berdasarkan hasil uji korelasi Rank Spearman, diketahui bahwa ada hubungan Kecemasan anak ditinjau dari kecemasan orang tua di RSU. Bhakti Husada Krikilan Banyuwangi Tahun 2020 karena nilai probabilitasnya $(\alpha)$ lebih kecil dari 0,05 yaitu 0.025. sementara itu tingkat korelasi diantara kedua variable dalam kategori cukup dikarenakan koefisien korelasinya 0.319 . Dengan demikian dapat ditarik satu kesimpulan bahwa Ha diterima dan $\mathrm{H}_{0}$ dapat tolak yang artinya ada hubungan Kecemasan anak ditinjau dari kecemasan orang tua di RSU. Bhakti Husada Krikilan Banyuwangi Tahun 2020.

\section{PEMBAHASAN}

Berdasarkan table 3 diatas diketahui bahwa hasil uji statistic dengan menggunakan uji korelasi Rank Spearman didapatkan $\alpha$ 0.025. Untuk menguji hipotesa peneliti menggunakan nilai $\alpha$. Berdasarkan hasil uji korelasi Rank Spearman, diketahui bahwa ada hubungan Kecemasan anak ditinjau dari kecemasan orang tua di RSU. Bhakti Husada Krikilan Banyuwangi Tahun 2020 karena nilai probabilitasnya $(\alpha)$ lebih kecil dari 0,05 yaitu 0.025. Dengan demikian dapat ditarik satu kesimpulan bahwa Ha diterima dan $\mathrm{H}_{0}$ dapat tolak yang artinya ada hubungan Kecemasan anak ditinjau dari kecemasan orang tua di RSU. Bhakti Husada Krikilan Banyuwangi Tahun 2020.

Ansietas ataupun kecemasan merupakan perasaan takut yang tidak nyata yang berhubungan dengan perasaan tidak tentu serta tidak berakal. Kondisi ini tidak mempunyai subjek yang khusus( Stela, 2013). Reaksi kecemasan ialah perihal yang sangat biasa yang dirasakan orang tua kala terdapat permasalahan kesehatan pada buah hatinya, sebab anak merupakan bagian dari kehidupan orang tuanya alhasil bila terdapat pengalaman yang menganggu kehidupan anak hingga orang tua juga merasa takut ataupun stress( Supartini, 2012). Hasil riset yang dilakukan oleh Geraw dalam ( 2011) melaporkan di New York menyatakan dari 50 ribu orang tua yang buah hatinya dirawat dibeberapa rumah sakit di kota New York, $30 \%$ hadapi kecemasan yang berat.

Kecemasan orang tua bisa dipengaruhi oleh berbagai aspek, salah satunya ialah lama hari perawatan anak. Lama perawatan anak bisa diukur serta ditaksir, lama perawatan anak yang memanjang diakibatkan oleh situasi medis penderita ataupun terdapatnya peradangan nosokomial( Depkes diambil oleh Reporter, 2012). Hasil riset yang dilakukan oleh Tistiawati( 2015) di rumah sakit Islam Impian Tegal Surakarta didapatkan hasil ada pengaruh yang positif antara tingkatan stress dengan lama perawatan anak dimana hal tersebut dapat meningkatan stress yang pada orang tua.

Berdasarkan hasil penelitian pada kecemasan orang tua menunjukkan bahwa sebagian besar responden memiliki kecemasan dalam kategori sedang sebanyak 33 orang $(67.3 \%)$. Dan pada kecemasan anak menunjukkan bahwa sebagian besar responden memiliki kecemasan dalam kategori berat sebanyak 28 orang (57.1\%). Bedasarkan analisis statistic hubungan kecemasan orang tua memiliki hubungan dengan kecemasan anak yang menjalani hospitaslisasi menunjukkan nilai signifikansi 0.025 dan itu $<$ dari $\alpha<0.05$. Dari kondisi diatas menunjukkan bahwa 
kecemasan orang tua memiliki hubungan dengan kecemasan anak yang menjalani hospitaslisasi.

Berdasarkan hasil penelitian menunjukkan hamper setengah responden ber usia 31-40 tahun sebanyak 18 orang $(37 \%)$. Berdasarkan hasil tabulasi silang antara usia responden dengan tingkat kecemasan menunjukkan bahwa $70,6 \%$ responden dengan tingkat kecemasan sedang barada pada rentang usia 20-30 tahun. Untari (2014), menyatakan bahwa tingkat kematangan usia berbanding lurus dengan perilaku dan tindakan. Kecemasan memang sering terjadi pada usia 21-45 tahun.

Sementara itu dari pendidikan diketahui bahwa hamper setengah responden memiliki pendidikan masing-masing SD dan SMP sebanyak masing-masing 24 orang (49\%). Berdasarkan hasil tabulasi silang antara pendidikan dengan kecemasan menunjukkan

bahwa 79, 24\% berpendidikan SMP. Untari (2014), menjelaskan bahwa orang dengan pendidikan kurang mudah merasakan kecemasan, karena semakin tinggi pendidikan berbanding lurus dengan kemampuan berfikir. Tingkat pendidikan juga akan mempengaruhi keputusan yang diambil secara rasional dalam mencerna informasi baru dan menganalisanya.

Seseorang pada usia 31-40 tahun dan pendidikan SMP telah mengalami kematangan dalam hal proses berfikir dan mengambil keputusan. Pada usia tersebut seseorang karena pengalamanya akan menjadi lebih dewasa dan bijaksana dalam berfikir sehingga akan menurunkan kecemasan ketika anaknya dirawat di Rumah Sakit.

Berdasarkan hasil penelitian diketahui bahwa sebagian besar responden berusia antara 4-5 tahun sebanyak 25 orang (51\%). Berdasarkan tabulasi silang antara usia dan kecemasan anak menunjukkan bahwa $64 \%$ anak dengan mecemasan berat berusia antara 4-5 tahun. Menurut Supartini (2012), usia anak memiliki pengaruh terhadap kecemasan pada anak saat hospitalisasi.
Kecemasan ini berkaitan dengan tahap pertumbuhan dan perkembangan anak.

Sementara berdasarkan tabulasi silang antara jenis kelamin dengan kecemasan menunjukkan bahwa $68 \%$ anak dengan kecemasan berat ber jenis kelamin laki-laki. Menurut Supartini (2012), jenis kelamin memiliki pengaruh terhadap kecemasan pada anak saat hospitalisasi. Perkembangan psikis anak perempuan biasanya berkembang lebih awal dibandingkan dengan laki-laki, sehingga akan memiliki dampak terhadap kecemasan anak.

Orang tua dengan perasaan cemas berlebih cenderung lebih takut terhadap halhal yang belum pasti. Ini membuat mereka tidak memperhatikan betul apa yang sebenarnya sedang terjadi dan apa yang ada di hadapan mereka. Sehingga, hal tersebut akan membuat pola asuh tidak berjalan sebagaimana mestinya. Kondisi inilah yang ikut memicu terjadinya kecemasan pada anak. Selain itu anak-anak biasanya mampu meraskan apa yang kita rasakan. Mereka akan merasa sedih dan cemas ketika kita sebagai orang tua merasakan sedih dan cemas. Orang tua manapun akan mesasakan cemas ketika anaknya dirawat di rumah sakit. Jangan tunjukkan perasaan cemas itu jika tidak ingin anak anda juga merasakan kecemasan seperti yang anda rasakan atau bahkan lebih (Tistiawati, 2015)

\section{KESIMPULAN}

Ada hubungan Kecemasan anak ditinjau dari kecemasan orang tua di RSU. Bhakti Husada Krikilan Banyuwangi

\section{Implikasi \\ Untuk dapatnya meningkatkan pendampingan kepada anak untuk memberikan rasa aman dan nyaman sehingga kecemasan anak akan menurun. Kepada perawat sebaiknya memberikan konseling kepada keluarga dan juga memberikan dukungan psikologis sehingga dapat mengurangi kecemasan orang tua}




\section{DAFTAR PUSTAKA}

Burnsnader, S., CCLS., \& Hernandezreif, M. (2014). The Impact of Play Therapy on Developmental Fears among Preschoolers. International Research Journal of Applied and Basic Sciences, 4 (7), 1740-1745.

Kumayah (2011) Physiologic and psychologic benefits of therapeutic storytelling to inpatient children. Jurnal keperawatan, 1(1), 71-74

Lemos et al (2016), Therapeutic Play Use in Children under the Venipucture: A Strategy for Pain Reduction. American Journal of Nursing Research, 4(1), 1-5

Majdaleni, 2014. Buku Panduan Praktikum Psikologi Dasar (Diktat). Bandung: Fakultas Psikologi Universtias Kristen

Nurmi, 2016. Analisis kecemasan orang tua dan anak dalam pemasangan infus pada anak balita di RSUD. Syekh Yusuf Kabupaten Gowa, Skripsi tidak dipublikasikan, Fakultas Kedokteran dan Ilmu Kesehatan Universitas Islam Negeri Alaudin

Purwandari, 2013. Pengaruh Terapi Seni Terhadap Kecemasan Anak Usia. Sekolah Selama Hospitalisasi di RSMS. Skripsi Tidak Dipublikasikan Fakultas Ilmu Keperawatan Universitas Indonesia

Ramdaniati, dkk, 2016. Comparison Study of Art Therapy and Play Therapy in. Page 3. Reducing Anciety on PreSchool Children Who Experince. Hospitalization.

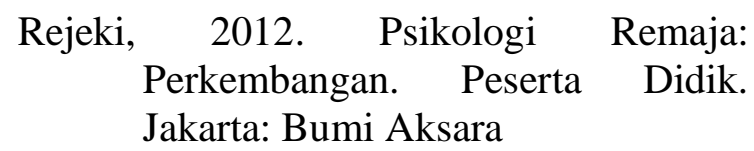

Saputro, 2017. Penurunan tingkat kecemasan anak akibat hospitalisasi dengan penerapan terapi bermain, Jurnal Konseling Indonesia, 3 (1), 912

Supartini. 2012. Buku ajar konsep dasar keperawatan anak. Jakarta. EGC

Stella E. Lumiu, 2013. hubungan dukungan keluarga dengan tingkat kecemasan akibat hospitalisasi pada anak usia pra sekolah di Irina E Blu Rsup Prof Dr R.D Kandou Manado. Jurnal Keperawatan, 1 (1), 1-8

Tistiawati, 2015. Pengaruh permainan terapeutik terhadap kecemasan, kehilangan kontrol, dan ketakutan anak prasekolah selama dirawat di RSUD Dr. H. Abdul Moeloek Provinsi Lampung. Tesis Fakultas Ilmu Keperawatan Universitas Indonesia.

Untari, 2014. Faktor-Faktor yang Mempengaruhi. Kecemasan pada Usia Pertengahan dalam Menghadapi Proses Menua. Jurnal Keperawatan Akper, 2 (2), 19-26

Wartawan, 2012. Dampak hospitalisasi terhadap perkembangan anak. Jurnal ilmiah widya. 2(2), 9-20.

Wong, Hockenberry \& Marylin, 2017. Buku Ajar Keperawatan Pediatric. Jakarta: EGC. 